\title{
Yield of maize grain and tropical grass species under intercropping management system using nicosulfuron herbicide in off-season cultivation
}

\author{
Armindo Neivo Kichel ${ }^{1}$, Luiz Carlos Ferreira de Souza ${ }^{2}$, Ademar Pereira Serra ${ }^{1 *}$, Roberto Giolo de Almeida ${ }^{1}$ \\ ${ }^{1}$ Embrapa Beef Cattle, Campo Grande, Mato Grosso do Sul, Brazil \\ ${ }^{2}$ Universidade Federal da Grande Dourados (UFGD), Post-Graduation Program in Agronomy, City of Dourados, State \\ of Mato Grosso do Sul, Brazil
}

*Corresponding author: ademar.serra@embrapa.br

\begin{abstract}
This research aimed to evaluate the maize grain yield and forage of grass species under intercropping system using nicosulfuron herbicide. In order to assess the parameters related to maize, a randomized block design was defined. The treatments were arranged in a $(5 \times 2+1) \times 2$ factorial design with four repetitions resulting in 11 treatments, where maize was cultivated under intercropping condition with different forage species (5) (Brachiaria brizantha cv. Marandu, Piatã, Xaraés, Brachiaria ruziziensis and Panicum maximum cv. Mombaça) and maize monoculture (1) as control treatment, with and without nicosulfuron herbicide application (2) in two growing seasons (2014 and 2015). The off-season intercropping of maize with tropical forage grasses with and without herbicide suppression decreased maize grain yield. The suppression with nicosulfuron herbicide decreased the dry matter production of forage grasses. Intercropping of $P$. maximum cv. Mombaça with maize showed higher decrease in maize grain yield. On the other hand, it showed higher forage grasses production for livestock feeding. B. brizantha cv. Piatã was the forage which less affected maize grain yield under intercropping, even with absence of nicosulfuron suppression. Off-season maize under intercropping with tropical forages can be used to recover degraded pastures; increasing forage dry matter production for livestock, remaining the soil covered with straws with possibility of no-till seeding for the next cultivation.
\end{abstract}

Keywords: Brachiaria spp, Panicum maximum, intercropped, pasture.

Abbreviations: ICLS_Integrated crop-livestock systems.

Introduction

The integrated crop-livestock systems are commonly used in Brazil, due to many benefits such as recovery of degraded pasture, increasing grain production, use of pasture in winter season for livestock grazing (Crusciol et al., 2014), resulting in higher efficiency of the lands. Aggregation of soil physical property and stability have been shown as a great contribution for production of forage species under rotation with grain crops (Viaud et al., 2018). However, many farmers in Brazil still insist rotation of soybean with maize without insertion of maize intercropping with forage grasses species. The intercropping of maize with forage grasses may be considered as jeopardy for some farms, because of the idea that maize grain yield is decreased due to interspecific competition, besides higher cost of crop-livestock implementation. As reported by Asai et al. (2018), the cost related to collective decision making, monitoring and operational cost are considered critical issues to implement integrated crop-livestock systems.

Intercropping increases the above-ground dry matter and improves the sustainability of no-till seeding, which is widely spread in Brazil and in more than $70 \%$ of the farms in South America (Derpsch et al., 2010). However, the time of forage sowing under intercropping is quite important to decrease interspecific competition (Tsumanuma et al., 2012). The simultaneous seeding of maize with forage grasses or seeding the forage at the same time has resulted in different competition depending on the forage species in intercropping (Crusciol et al., 2013). In Brazil, the forage grasses are commonly sown at the same time of maize with the possibility of using herbicide suppression in such occasions.

The no-till system alone is not sufficient for improvement of soil physical, chemical and microbial properties. Thus, the use of livestock into the integrated systems is decisive to have progressive results in terms of soil quality (Lourente et al., 2016). The weather condition in most regions of Brazil allows the cropping of soybean, followed by maize intercropped with forage species (Fortes et al., 2016). Thereafter, it is possible to cultivate soybean followed by maize along with three months of pasture for livestock grazing. Nevertheless, the intercropping of two species usually results in decreasing yield of one in detriment of another (Calonego et al., 2011). In most circumstances, maize is intercropped with B. ruziziensis. However, in tropical climate there are many other options of forage grasses species to be introduced into this intercropping system. The species B. brizantha cv. Marandu, Piatã, Paiaguas, Xaraés and $P$. maximum cv. Massai, Mombaça, Zuri, can be included among other species of forages grasses 
(Borghi et al., 2013a; Crusciol et al., 2010). Conversely, the interspecific competition and consequently decreasing of maize grain yield tends farmers to refrain cultivation of the most species mentioned above. Freitas et al. (2014), reported that there is competition between maize with $B$. brizantha cv. BRS Piatã and the application of below-rate of nicosulfuron herbicide ( $8 \mathrm{~g}$ a.i. $\mathrm{ha}^{-1}$ ) may decrease this competition, especially under higher $B$. brizantha $\mathrm{cv}$. BRS Piatã seeding rate ( 4 to $6 \mathrm{~kg} \mathrm{ha}^{-1}$ of viable pure seeds).

In order to obtain the maximum benefits of maize intercropping with forage species, it is relevant to figure out the degree of competition between species to make the viability of this intercropping possible. The study of herbicide suppression management, associated with different forage grass species under intercropping with maize might achieve the best combination, resulting in better grain yield, forage dry matter production and increment in farmer economic returns.

This research aimed to evaluate the yield of some forage grass species and maize grain yield under intercropping with nicosulfuron herbicide suppression to explore better alternative for maize grain yield, forage grass production and soil covered with straws for no-till seeding.

\section{Results and Discussion}

\section{Analysis of variance (ANOVA) of the parameters assessed}

The growing seasons affected the majority of analyzed variables, except for harvest index (HI) (Table 1). Herbicide management showed significant difference only for ear grain weight (EGW) and maize grain yield (MGY) (Table 1). The cropping systems (maize intercropping with forage grass species) resulted in significant effect on MGY, above-ground maize dry matter (AMDM), stem diameter (SD), ear length (EL), EGW, No. of grain per row (NGR) and $\mathrm{HI}$ (Table 4). Besides the major effect of the treatments, interactive effect was observed for growing seasons vs. cropping systems on No. of grain row per ear (NGRE) and interactive effects on growing seasons vs. cropping systems on AMDM, $\mathrm{HI}$ and SD.

The intercropped forage grass species can affect EL, EGW, NGR, HI, SD, AMDM and MGY. However, no significant effect of forages species among the cropping systems was observed for No. of ear per hectare (NE), NGR, 1000 grain weight (1000-GW) and NGE.

\section{Growing seasons affects maize traits}

The first growing season (2014) showed better results for maize stand (MS), No. of ear per hectare (NEH), EL, EGW, 1000-GW and MGY. However, in 2015 growing season a higher NGE and NGR was observed (Table 2).

Even with higher rainfall in 2015 growing season, the MGY showed $16.80 \%$ less grain yield which was related to lower radiation due to many cloudy days resulted to $215 \mathrm{~mm}$ rainfall during May 2015. These conditions occurred during the $\mathrm{R} 1$ and $\mathrm{R} 3$ reproductive maize stage. As reported by Didonet et al. (2002), decreasing in soil radiation ranges from $30 \%$ to $40 \%$ can decline the maize productive potential, which may decrease the photosynthesis capacity and consequently reduction in maize grain yield.

Effects of herbicide management on ear grain weight and maize grain yield

Spraying of nicosulfuron herbicide to suppress the forages growth in intercropping with maize resulted in significant $(P<0.01)$ increase in grain weight per ear $(G W E)$ and maize grain yield (MGY) (Figure $1 \mathrm{~A}$ and $\mathrm{B}$ ). The absence of herbicide on maize intercropping with forages grasses decrease the average GWE on average $7 \mathrm{~g}$, consequently decreasing $450 \mathrm{~kg} \mathrm{ha}^{-1}$ of MGY. These results indicated the competition among forage grasses and maize, which must be well comprehended to avoid economic loss. Application of nicosulfuron herbicide (at rate of $6 \mathrm{~g}$ a.i. ha$\left.{ }^{1}\right)$ did not affect grain yield because it did not kill the forage grass species in intercropping with maize. However, in previous researches we observed that 8-16 g a.i. ha ${ }^{-1}$ of nicosulfuron did not affect maize grain yield in intercropping with Brachiaria ruziziensis (Ceccon et al., 2010). Nevertheless, many other factors are related to the competition of maize intercropping with forage grass, as the case of forage grass stand and the forage grasses species used in intercropping (Pariz 2011; Vidal 2010).

\section{The effects of cropping systems on grain weight per ear, ear length and maize grain yield}

Maize intercropping with $P$. maximum $\mathrm{cv}$. Mombaça resulted in lower GWE in comparison to maize monoculture. However, no significant difference $(P>0.05)$ was observed between the other intercropping in comparison to $P$. maximum cv. Mombaça (Figure 2A). These results indicated that EGW of maize monoculture did not differ from maize intercropping $B$. brizantha cv. Marandu, Xaraés, Piatã e Brachiaria ruziziensis. Higher ear lengths were observed in maize monoculture and maize intercropping with $B$. brizantha $\mathrm{cv}$. Xaraés, $B$. ruziziensis and $P$. maximum $\mathrm{cv}$. Mombaça (Figure 2B). Conversely, maize intercropping with B. brizantha cv. Marandu and Piatã showed lower ear length. However, maize grain yield in monoculture showed higher grain yield in comparison to intercropping. Among intercropping, the markedly difference was between maize intercropping with $B$. brizantha cv. Piatã which showed higher grain yield in comparison to intercropping with $P$. maximum $\mathrm{cv}$. Mombaça (Figure $2 \mathrm{C}$ ). The maize intercropping with any forage grass species assessed in this research resulted in decreasing maize grain yield, which achieved the maximum decrease in maize, when intercropped with $P$. maximum cv. Mombaça that reduced maize grain yield up to $20.15 \%$.

\section{Interactive effects between growing seasons vs. cropping} systems

Interactive effects were observed between growing seasons vs. cropping systems on above-ground maize dry matter (AMDM), harvest index (HI) and stem diameter (SD). In 2014 growing season, the AMDM among the cropping systems differed just for maize intercropping with $B$. ruziziensis, which showed lower amount of AMDM (Figure 3A). On the other hand, in 2015 growing season the results for marandu, 
Table 1. Analysis of variance for maize traits intercropped with forage grasses species with and without herbicide suppression in two growing seasons.

\begin{tabular}{|c|c|c|c|c|c|c|c|c|}
\hline \multirow{3}{*}{ Variables } & \multicolumn{8}{|c|}{ Source of variation } \\
\hline & Blocks & $\begin{array}{c}\text { Growing } \\
\text { season (GS) }\end{array}$ & $\begin{array}{c}\text { Herbicide } \\
\text { management } \\
(\mathrm{HM}) \\
\end{array}$ & $\begin{array}{c}\text { Cropping } \\
\text { systems } \\
\text { (CS) }\end{array}$ & GSxHM & GSxCS & $\mathrm{HMxCS}$ & GSxHMxCS \\
\hline & \multicolumn{8}{|c|}{ F-value } \\
\hline MS & $3.035^{*}$ & $5.071^{*}$ & $1.016^{\mathrm{ns}}$ & $0.843^{\mathrm{ns}}$ & $0.004^{\text {ns }}$ & $0.316^{\mathrm{ns}}$ & $0.792^{\mathrm{ns}}$ & $0.427^{\mathrm{ns}}$ \\
\hline NME & $4.337 * *$ & $7.194 * *$ & $1.882^{\mathrm{ns}}$ & $1.036^{\mathrm{ns}}$ & $0.010^{\text {ns }}$ & $0.405^{\mathrm{ns}}$ & $0.548^{\mathrm{ns}}$ & $0.167^{\mathrm{ns}}$ \\
\hline EL & $1.863^{\text {ns }}$ & $4.546 *$ & $0.888^{\text {ns }}$ & $2.348 *$ & $0.370^{\text {ns }}$ & $0.935^{\mathrm{ns}}$ & $0.487^{\mathrm{ns}}$ & $0.566^{\mathrm{ns}}$ \\
\hline NRE & $2.195^{\mathrm{ns}}$ & $56.369 * *$ & $0.076^{\mathrm{ns}}$ & $0.582^{\mathrm{ns}}$ & $5.524^{*}$ & $0.385^{\mathrm{ns}}$ & $0.839^{\mathrm{ns}}$ & $1.041^{\mathrm{ns}}$ \\
\hline GWE & $5.367 * *$ & $6.123 * *$ & $4.853^{*}$ & $3.057^{*}$ & $1.925^{\mathrm{ns}}$ & $0.785^{\mathrm{ns}}$ & $0.319^{\mathrm{ns}}$ & $0.351^{\mathrm{ns}}$ \\
\hline $1000 \mathrm{GW}$ & $0.904^{\mathrm{ns}}$ & $186.804 * *$ & $0.776^{\mathrm{ns}}$ & $1.941^{\mathrm{ns}}$ & $1.427^{\mathrm{ns}}$ & $0.656^{\mathrm{ns}}$ & $1.345^{\mathrm{ns}}$ & $0.266^{\mathrm{ns}}$ \\
\hline NGE & $3.196 *$ & $27.254^{* *}$ & $1.905^{\mathrm{ns}}$ & $1.517^{\mathrm{ns}}$ & $0.298^{\mathrm{ns}}$ & $0.596^{\mathrm{ns}}$ & $0.483^{n s}$ & $0.459^{\mathrm{ns}}$ \\
\hline MGY & $1.308^{\mathrm{ns}}$ & $57.518^{* *}$ & $15.943 * *$ & $12.116^{* *}$ & $1.940^{\mathrm{ns}}$ & $1.987^{\mathrm{ns}}$ & $0.706^{\mathrm{ns}}$ & $0.118^{\mathrm{ns}}$ \\
\hline ANDN & $0.453^{\text {ns }}$ & $34.673^{* *}$ & $2.363^{\mathrm{ns}}$ & $4.267 * *$ & $0.216^{\mathrm{ns}}$ & $2.512^{*}$ & $0.555^{\mathrm{ns}}$ & $0.073^{\mathrm{ns}}$ \\
\hline $\mathrm{HI}$ & $0.467^{\mathrm{ns}}$ & $0.392^{\text {ns }}$ & $2.027^{\mathrm{ns}}$ & $2.624^{*}$ & $3.139^{\text {ns }}$ & $2.761^{*}$ & $1.024^{\mathrm{ns}}$ & $0.424^{\mathrm{ns}}$ \\
\hline NGR & $1.121^{\mathrm{ns}}$ & $8.803 * *$ & $0.116^{\text {ns }}$ & $2.874 *$ & $1.118^{\mathrm{ns}}$ & $1.342^{\mathrm{ns}}$ & $1.307^{\mathrm{ns}}$ & $0.345^{\mathrm{ns}}$ \\
\hline SD & $3.253^{*}$ & $569.258 * *$ & $1.241^{\mathrm{ns}}$ & $8.577 * *$ & $2.331^{\mathrm{ns}}$ & $4.124 * *$ & $0.736^{\mathrm{ns}}$ & $0.861^{\mathrm{ns}}$ \\
\hline
\end{tabular}

*significant at $\mathrm{p}<0.05$; **significant at $\mathrm{p}<0.01$ by $\mathrm{F}$-value; $\mathrm{ns}=$ no significant. Maize stand (MS), No. of maize ears (NME), stem diameter (SD), ear diameter (ED), ear length (EL), No. of rows per ear (NRE), No. of grain per row (NGR), 1000 grains weight (100GW), maize grain yield (MGY), grain weight per ear (GWE), No. of grain per ear (NGE), above-ground maize dry matter (AMDM), and harvest index (HI).
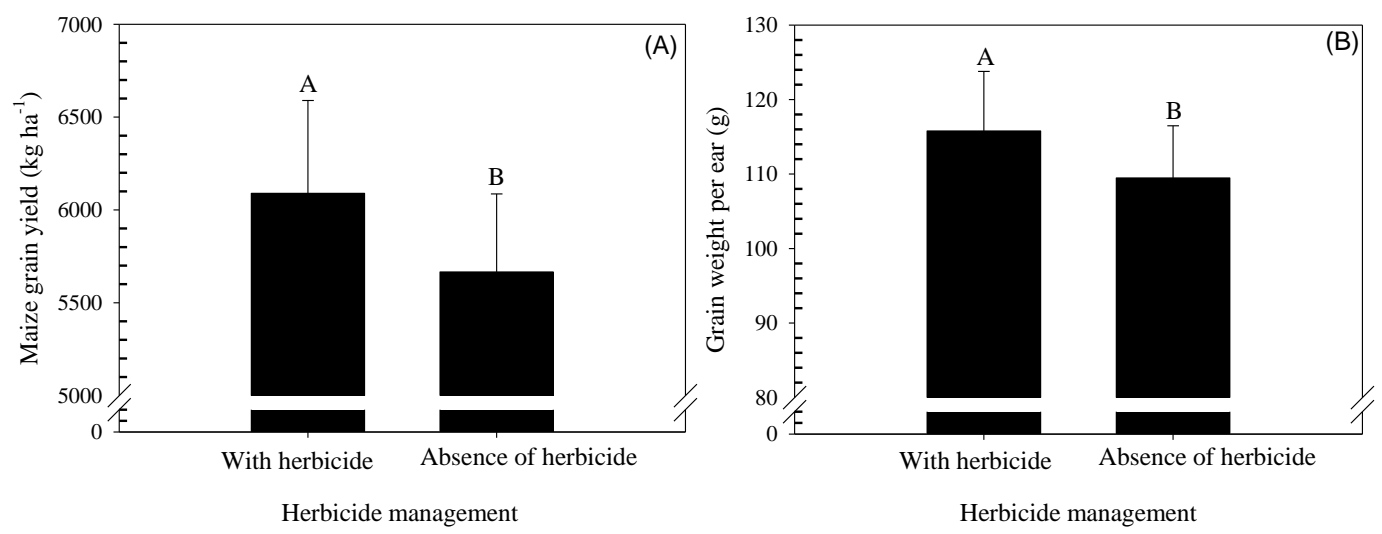

Fig 1. Grain yield per ear and maize grain yield affected by the herbicide management to suppress forage growth. Means followed by the same uppercase letters do not differ by t-test of means at $5 \%$ probability.

Table 2. T-test of means for maize traits compared in two cropping seasons.

\begin{tabular}{lcc}
\hline Variables & Growing seasons & Mean \pm standard error \\
\hline Maize stand & 2014 & $54,745.33 \pm 322 \mathrm{~A}$ \\
& 2015 & $52,314.77 \pm 1.012 \mathrm{~B}$ \\
\hline No. of ears per hectare & 2014 & $54,050.83 \pm 346 \mathrm{~A}$ \\
& 2015 & $51,018.47 \pm 1.080 \mathrm{~B}$ \\
\hline Ear length & 2014 & $12.45 \pm 0.079 \mathrm{~A}$ \\
& 2015 & $12.03 \pm 0.187 \mathrm{~B}$ \\
\hline Grain weight per ear & 2014 & $116.17 \pm 1.178 \mathrm{~A}$ \\
& 2015 & $109.09 \pm 2.929 \mathrm{~B}$ \\
\hline 1000 grain weight & 2014 & $361.03 \pm 2.416 \mathrm{~A}$ \\
& 2015 & $293.46 \pm 4.342 \mathrm{~B}$ \\
\hline No. of grain rows per ear & 2014 & $14.49 \pm 0.115 \mathrm{~B}$ \\
& 2015 & $15.68 \pm 0.111 \mathrm{~A}$ \\
\hline No. of grain per ear & 2014 & $335.30 \pm 2.66 \mathrm{~B}$ \\
& 2015 & $391,96 \pm 3,11 \mathrm{~A}$ \\
\hline Maize grain yield & 2014 & $6,279,35 \pm 52,1 \mathrm{~A}$ \\
& 2015 & $5,475,86 \pm 43,2 \mathrm{~B}$ \\
\hline
\end{tabular}

Means followed by the same uppercase letters do not differ by t-test of means at $5 \%$ probability. 


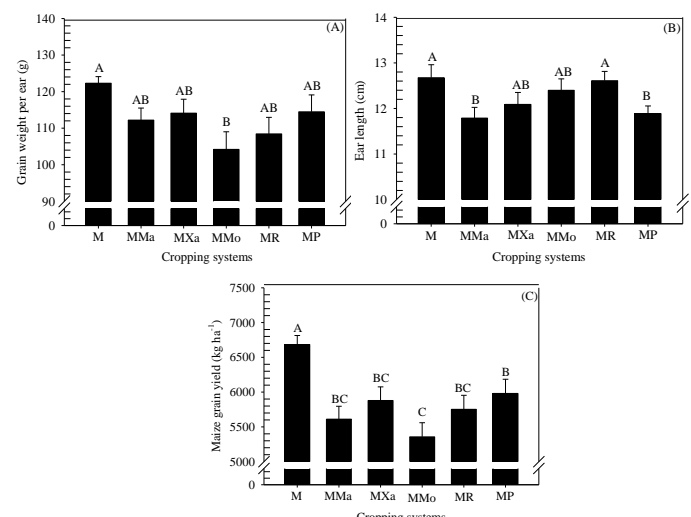

Fig 2. Grain weight per ear (A), ear length (B) and maize grain yield (C) affected by cropping systems. Maize monoculture (MM), maize intercropping with Brachiaria brizantha cv. Marandu (MMa), Xaraés (MXa), Piatã (MPi), maize intercropping with $B$. ruziziensis, and $P$. maximum cv. Mombaça. Means followed by the same uppercase letters do not differ by $\mathrm{t}$-test of means at $5 \%$ probability. $\mathrm{CV}=$ coefficient of variation.

Table 3. Summary of analysis of variance (ANOVA) for above-ground forage dry matter under intercropping with maize with and without herbicide suppression in two growing seasons.

\begin{tabular}{|c|c|c|c|c|}
\hline Source of variation & Degrees of freedom & Median square & $F$-value & $P$-value \\
\hline Growing season (GS) & 1 & 25847421.612 & 123.957 & 0.0000 \\
\hline Herbicide management (HM) & 1 & 214155673.512 & 1027.034 & 0.0000 \\
\hline Cut age (CA) & 3 & 343095559.208 & 1645.396 & 0.0000 \\
\hline Cropping systems (CS) & 4 & 11766157.910 & 56.427 & 0.0000 \\
\hline Block & 3 & 203392.208 & 0.975 & 0.4048 \\
\hline GS*HM & 1 & 3287794.050 & 15.767 & 0.0001 \\
\hline GS*CS & 4 & 15536693.320 & 74.510 & 0.0000 \\
\hline $\mathrm{GS} * \mathrm{CA}$ & 3 & 991988.839 & 4.757 & 0.0010 \\
\hline $\mathrm{HM}^{*} \mathrm{CS}$ & 4 & 917918.598 & 4.402 & 0.0019 \\
\hline $\mathrm{HM}^{*} \mathrm{CA}$ & 3 & 9191820.304 & 44.082 & 0.0000 \\
\hline$C A^{*} \mathrm{CS}$ & 12 & 1221713.085 & 5.859 & 0.0000 \\
\hline $\mathrm{HM}^{*} \mathrm{CA}^{*} \mathrm{CS}$ & 12 & 385698.577 & 1.850 & 0.0412 \\
\hline GS*HM*CA & 3 & 3533803.675 & 16.947 & 0.0000 \\
\hline $\mathrm{GS}^{*} \mathrm{CA}^{*} \mathrm{CS}$ & 12 & 729364.130 & 3.498 & 0.0001 \\
\hline GS*HM*CS & 4 & 181952.026 & 0.873 & 0.4809 \\
\hline Error & 249 & 208518.551 & & \\
\hline
\end{tabular}



Fig 3. Interactive effects between growing seasons and cropping systems under above-ground maize dry matter (A), harvest index (B), and stem diameter (c). Means followed by the same uppercase letters do not differ by t-test of means at $5 \%$ probability. Maize monoculture (MM), maize intercropping with Brachiaria brizantha cv. Marandu (MMa), Xaraés (MXa), Piatã (MPi), maize intercropping with $B$. ruziziensis, and $P$. maximum cv. Mombaça. Means followed by the same uppercase letters do not differ by $t-$ test of means at $5 \%$ probability. $\mathrm{CV}=$ coefficient of variation. 
Table 4. Interactive effects of herbicide management vs. cropping systems vs. cut age on above-ground forage dry matter.

\begin{tabular}{|c|c|c|c|c|c|c|}
\hline \multirow[b]{2}{*}{$\begin{array}{l}\text { Herbicide } \\
\text { management }\end{array}$} & \multirow[b]{2}{*}{$\begin{array}{l}\text { Cropping } \\
\text { systems }\end{array}$} & \multicolumn{4}{|c|}{ Cut age - DAE } & \multirow[b]{2}{*}{ Equation } \\
\hline & & 50 & 90 & 135 & 180 & \\
\hline \multirow{4}{*}{$\begin{array}{c}\text { Herbicide } \\
\text { suppression }\end{array}$} & MMa & $473 \mathrm{Ba}$ & $1121 \mathrm{Bb}$ & $2011 \mathrm{Bb}$ & $4405 B c d$ & $Y=1048.621-21.018 x+0.2185 x^{2} R^{2}=0.99$ \\
\hline & MMo & 593Ba & 1629Ba & 3398Ba & $5548 \mathrm{Ba}$ & $Y=-1041.026+52.276 x-0.0113 x^{2} R^{2}=0.98$ \\
\hline & $\mathrm{MR}$ & 501Ba & $1132 \mathrm{Bb}$ & $1894 \mathrm{Bb}$ & $4806 \mathrm{Bbc}$ & $Y=-223.493+9.872 x+0.1236 x^{2} R^{2}=0.99$ \\
\hline & MP & $593 \mathrm{Ba}$ & $1201 \mathrm{Bb}$ & $2513 \mathrm{Bb}$ & 5075Bab & $Y=1096.773-21.531 x+0.2416 x^{2} R^{2}=0.98$ \\
\hline \multirow{4}{*}{$\begin{array}{l}\text { Absence of } \\
\text { herbicide } \\
\text { suppression }\end{array}$} & $\mathrm{MXa}$ & $1094 \mathrm{Ab}$ & 2304Ac & $4250 \mathrm{Ac}$ & 6169Abc & $Y=1014.995-19.870 x+0.490 x^{2}-0.001 x^{3} R^{2}=0.99$ \\
\hline & MMo & $1631 \mathrm{Aa}$ & 3336Aa & $6032 \mathrm{Aa}$ & 7929Aa & $Y=2287.165-57.963 x+1.050 x^{2}-0.003 x^{3} R^{2}=0.99$ \\
\hline & MR & 1687Aa & $2574 \mathrm{Abc}$ & 4659Abc & 6321Abc & $Y=3673.459-87.574 x+1.106 x^{2}-0.003 x^{3} R^{2}=0.99$ \\
\hline & MP & $1312 \mathrm{Ab}$ & 2980Aab & $5276 \mathrm{Ab}$ & $6621 \mathrm{Ab}$ & $Y=1330.348-35.662 x+0.828 x^{2}-0.003 x^{3}=R^{2}=0.99$ \\
\hline
\end{tabular}

Means folowed by the same uppercase letters do not differ between herbicide management in each cut age by $t$-test of means at $5 \%$ probability, and the same lowercase letter do not differ amon the cropping systems in each cut age and herbicide management by Tukey test of means at $5 \%$ probability.
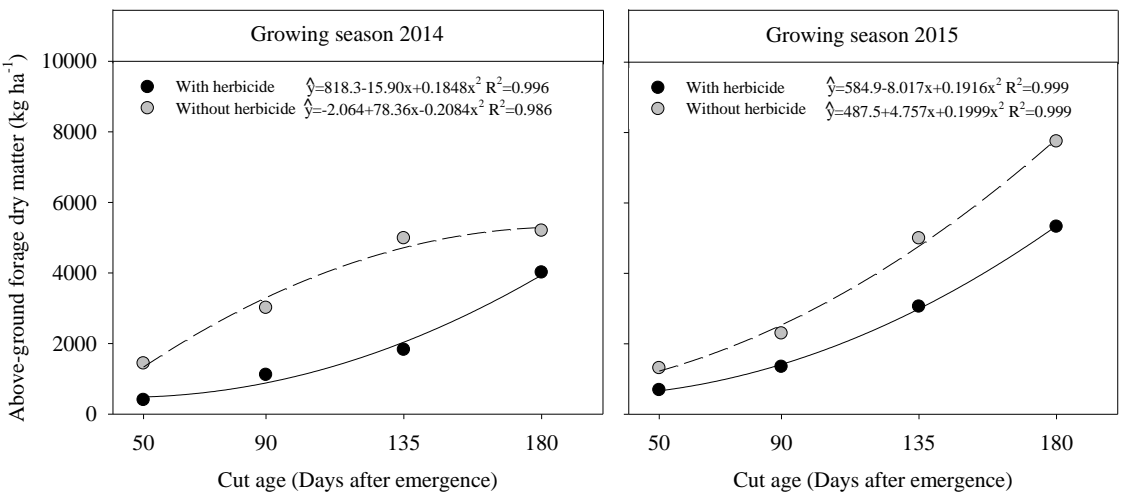

Fig 4. Interactive effects of growing season vs. herbicide management vs. cut age on above-ground forage dry matter.

Table 5. Experimental treatments assessed and respective abbreviation.

\begin{tabular}{lc}
\hline Cropping systems & Nicosulfuron herbicide management \\
\hline Maize monoculture & No \\
Maize intercropping with Brachiaria brizantha cv. Xaraés & Yes \\
Maize intercropping with Brachiaria brizantha cv. Piatã & Yes \\
Maize intercropping with Panicum maximum cv. Mombaça & Yes \\
Maize intercropping with Brachiaria ruziziensis cv. Kenedy & Yes \\
Maize intercropping with Brachiaria brizantha cv. Marandu & Yes \\
Maize intercropping with Brachiaria brizantha cv. Piatã & No \\
Maize intercropping with Panicum maximum cv. Mombaça & No \\
Maize intercropping with Brachiaria ruziziensis cv. Kenedy & No \\
Maize intercropping with Brachiaria brizantha cv. Marandu & No \\
Maize intercropping with Brachiaria brizantha cv. Xaraes & No \\
\hline
\end{tabular}

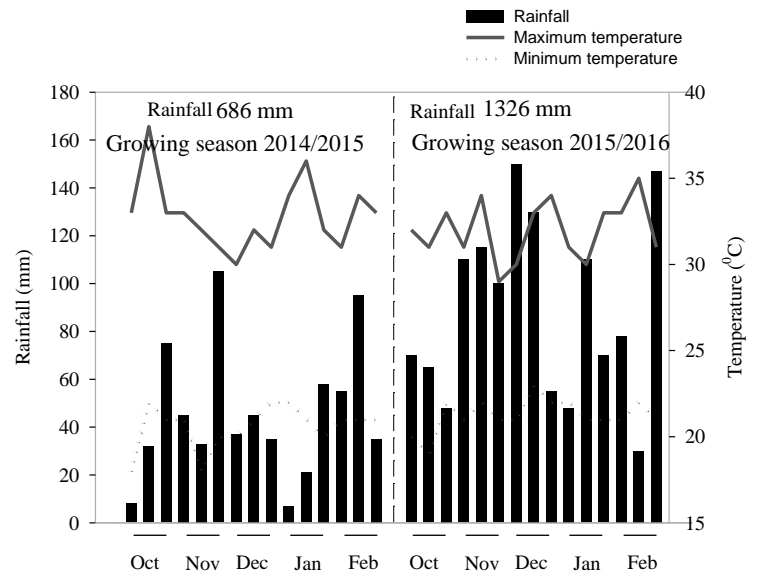

Growing seasons $(2014 / 2015-2015 / 2016)$

Fig 5. Rainfall (mm), maximum and minimum temperature (Co) per decennia from February (2014) to August (2014). Source: climate station of Universidade Federal da Grande Dourados (UFGD). 
xaraes and mombaça were not equal, which demonstrate that AMDM can change with the weather conditions in each year, but ruziziensis and piatã remained without alteration. This stability was observed for harvest index in ruziziensis and piatã (Figure $3 \mathrm{~B}$ ). When the weather condition was more favorable for maize growth, the stem diameter showed higher values, as the case of higher rainfall in 2015 growing season. However, the competition between maize and forage grasses resulted in lower SD in intercropping conmpared to maize monoculture (Figure $3 \mathrm{C}$ ).

\section{Production of dry matter in forage grasses in intercropping with maize}

The dry matter production of forage grasses species in intercropping with maize showed interactive effect for growing seasons vs. herbicide management vs. cutting age and herbicide management vs. cut age vs. cropping systems (Table 3). Thus, the interaction effects resulted in adjustment of regression models for cutting age of forages grasses.

For both growing seasons (2014 and 2015) we observed significant effect of herbicide management, which decreased above-ground forage dry matter (AFDM) (Figure 4). In 2014 growing season, the herbicide management was sprayed at 50 days after emergency (DAE) causing $63.7 \%$ reduction in AFDM in relation to absence of herbicide suppression. However, in 2015 growing season the same age achieved $45.9 \%$ of AFDM reduction. The herbicide suppression effects remained in the course of time until 180 DAE (Figure 4).

Harvesting maize at $135 \mathrm{DAE}$, showed that highest increment in AFDM was observed due to higher light incidence. At 180 DAE, the AFDM in 2014 growing season showed on average $4,000 \mathrm{~kg} \mathrm{ha}^{-1}$ with herbicide suppression and 5,289 $\mathrm{kg} \mathrm{ha}^{-1}$ without suppression. In 2015 growing season, the average AFDM was $5,359 \mathrm{~kg} \mathrm{ha}^{-1}$ with herbicide suppression and $7,818 \mathrm{~kg}^{\mathrm{ha}^{-1}}$ without herbicide suppression. As reported by Borghi et al. (2007), the shade of maize plants in intercropping with forage grasses decreased the leaves productions. Therefore, at the end of maize life cycle the sun light increases forage grasses photosynthesis, resulting in increment of forage biomass.

The suppression on forage grass species with below-rate nicosulfuron herbicide $\left(6 \mathrm{~g} \mathrm{ha}^{-1}\right)$, sprayed at $20 \mathrm{DAE}$, decreased the AFDM about $60.95 \%, 53.54 \%, 50 \%$ and $27.53 \%$, correspond to evaluation time of $50,90,135$ and $180 \mathrm{DAE}$, respectively. On average, the absence of herbicide suppression in two cropping seasons increased $34 \%$ of AFDM in 45 days (from 135 to 180 DAE) (Table 4). However, nicosulfuron spray increased $95 \%$ of AFDM from 135 to 180 DAE. The increment in AFDM was consequences of higher tillers and leaf growth after the effect of herbicide suppression and maize competition with forages grasses species.

In $50 \mathrm{DAE}$, the AFDM among the intercropping with maize did not differ under herbicide suppression. However, in the evaluation accomplished without herbicide suppression there was significant difference among the intercropping, resulting in higher AFDM for $P$. maximum cv. Mombaça and B. ruziziensis. Nevertheless, for evaluations at 90, 135 and 180 DAE, P. maximum cv. Mombaça showed higher AFDM than other forage grass species using either herbicide and without suppression. It followed by $B$. brizantha cv. Piatã
(Table 4). The increase in $P$. maximum cv. Mombaça dry matter resulted in decreasing maize grain yield, suggesting the competition between these species.

\section{Materials and Methods}

\section{Site and soil description}

This research was carried out in a Latossolo Vermelho (Rhodic Hapludox), with clayey texture and clay mineralogy constituted mainly by $\mathrm{Al} / \mathrm{Fe}$ oxy-hydroxides (Santos et al., 2013). The experimental site is located in the municipality of Dourados, state of Mato Grosso do Sul, Brazil (22 $14^{\circ} 08^{\prime \prime} \mathrm{S}$, $59^{\circ} 54^{\prime} 13^{\prime \prime} \mathrm{W}$, and $455 \mathrm{~m}$ above sea level). Soil samples were collected (0-0.20 $\mathrm{m}$ depth) in January 2014, before the establishment of the experiment in order to define the fertilizer rates and determine soil chemical and physical properties (Claessen, 1997): $\mathrm{pH}(\mathrm{CaCl} 2), 5.34 ; 22.08 \mathrm{~g} \mathrm{dm}^{-3}$ organic matter; $21.7 \mathrm{mg} \mathrm{dm}^{-3} \mathrm{P} ; 0.28 \mathrm{cmol}_{\mathrm{c}} \mathrm{dm}^{-3} \mathrm{~K}^{+} ; 4.56$ $\mathrm{cmol}_{\mathrm{c}} \mathrm{dm}^{-3} \mathrm{Ca}^{2+} ; 2.04 \mathrm{cmol}_{\mathrm{c}} \mathrm{dm}^{-3} \mathrm{Mg}^{2+} ; 5.09 \mathrm{cmol}_{\mathrm{c}} \mathrm{dm}^{-3} \mathrm{H}+\mathrm{Al}$; $0 \mathrm{cmol}_{\mathrm{c}} \mathrm{dm}^{-3} \mathrm{Al}^{3+} ; 8.68 \mathrm{cmol}_{\mathrm{c}} \mathrm{dm}^{-3}$ sum of base; $11.97 \mathrm{cmol}_{\mathrm{c}}$ $\mathrm{dm}^{-3}$ cations exchange capacity (CEC); $57.5 \%$ base saturation; and 610,90 and $300 \mathrm{~g} \mathrm{~kg}^{-1}$ of clay, silt and sand, respectively.

Rainfall data, maximum and minimum temperature in the experimental site are shown in Figure 5. Maize was cultivated from February to August of 2014 and 2015 growing seasons. According to Köppen (1948), the region has tropical climate (Cwa), with rainy summer and dry winter, with average rainfall of $1,428 \mathrm{~mm}$ and annual average temperature of $22.7^{\circ} \mathrm{C}$ (Arai et al., 2010).

\section{Experimental design and treatment implementation}

In order to assess the parameters related to maize, randomized blocks experimental design was defined, with the treatments arranged in a $(5 \times 2+1) \times 2$ factorial design, with four repetitions, resulting in 11 treatments with maize cultivated under intercropping with different forage grasses species (5) [Brachiaria brizantha cvs. (Marandu, Piatã and Xaraés), Brachiaria ruziziensis and Panicum maximum cv. Mombaça] and maize monoculture (1) as the control treatment, with and without nicosulfuron herbicide suppression (2) in two growing seasons (2014 and 2015) (Table 5).

The parameters related to above-ground dry matter production of maize intercropping with forage grasses species were arranged in a factorial design $(5 \times 2 \times 2)$, which was compiled by cropping systems with forage grasses species (5) [Brachiaria brizantha cvs. (Marandu, Piatã and Xaraés), Brachiaria ruziziensis and Panicum maximum cv. Mombaça], with and without nicosulfuron herbicide management in two growing seasons (2014 and 2015) in four repetitions. In order to determine the above-ground dry matter of forage grasses at cutting ages [50, 90, 135 and 180 days after emergence (DAE)], the experimental design was arranged in a $5 \times 4 \times 2 \times 2$ factorial, with cropping systems under five forages species [Brachiaria brizantha cvs. (Marandu, Piatã and Xaraés), Brachiaria ruziziensis and Panicum maximum cv. Mombaça] vs. cutting age [50, 90, 135 and 180 days after emergence (DAE)] vs. herbicide management (with and without nicosulfuron herbicide suppression) vs. growing seasons (2014 and 2015), with four repetitions. 


\section{Experiment implementation}

The experiment was implemented right after soybean harvest on March $15^{\text {th }}, 2014$, with simultaneous seeding of maize and forage grasses species. The maize harvest was accomplished on August $2^{\text {th }}, 2014$ and the forages evaluation in September 2014, the experiment was repeated at the same date in 2015. Each experimental unit had $15 \mathrm{~m}$ of width and $20 \mathrm{~m}$ of length $\left(300 \mathrm{~m}^{2}\right)$, with 11 units per blocks $\left(3,300 \mathrm{~m}^{2}\right)$, with four blocks. The seeding and all managements were conducted mechanically. Maize and forages sowing were conducted at the same date on March 14th and 16 th 2014 and 2015, which showed five days after sowing to emergency of maize and seven days for forages species.

Before seeding of forage grass species, the seed qualities were evaluated in order to pattern the seeds in relation to cultural values (CV). The samples were collected in an amount of 500 grams for each forage grass species, in which the purity and germination were determined. All the seeds were adjusted following the equation: $\mathrm{CV}=$ (germination $\mathrm{x}$ purity) $/ 100$, express in percentage, since $\mathrm{CV}=80 \%$ for Brachiaria and $50 \%$ for Panicum. The values related to the 1,000 seeds weight and the numbers of seeds per grams were obtained from eight samples (Table 2). The seeding rate for all forages species were determined based on seeds per square meter, aimed to obtain the same number of plants and uniformity to establish the forages. The seeding for Brachirias comprised of 70 viable pure seeds (VPS) per square meters, and for Panicum 350 VPS per square meter, resulting in 30 plants per square meter for Brachiaria and 60 plants per square meter for Panicum, as recommendation of Almeida et al. (2009).

The forages seeding was accomplished with a seeding drill before cultivation of maize, with eight rows space apart $0.4 \mathrm{~m}$ under no-till, with the seeds deposited $2-4 \mathrm{~cm}$ depth. The maize simple hybrid DKB 177 VT PRO was sown under no-till right after forages species, except for treatments with monoculture of forages. The maize seeding was accomplished with seeding-drill with four rows spaced apart in $0.9 \mathrm{~m}$ adjusted to seed 6-7 seeds per meter, in $2-5 \mathrm{~cm}$ deeper, resulting in an ending stand of 60,000 plants per hectare.

The fertilizer rate for maize was $250 \mathrm{~kg} \mathrm{ha}^{-1}$ of the formula 08-20-20 (N-P-K) without topdressing $\mathrm{N}$-fertilizer on the experiment. The cultural treats during maize and forages development were occurred at 18 to 20 days after forages emergence, in which atrazine herbicide $\left(1,500 \mathrm{~g} \mathrm{ha}^{-1}\right)$ was applied in the whole area to control broadleaf weeds. To control Spodoptera frugiperda, we applied the insecticide flubendiamida (70 $\mathrm{ml} \mathrm{ha}^{-1}$ in growth stage 6) and betaciflutrina associated with imidaclopid $\left(500 \mathrm{ml}\right.$ e.a. ha- ${ }^{-1}$ in growth stage 8).

The treatments related to the herbicide management was conducted with the herbicide nicosulfuron (6 $\mathrm{g}$ a.i. ha $\left.{ }^{-1}\right)$, which was applied just in the treatments with forage with herbicide suppression when the forage showed one to four tillers (18 to 20 days after emergency of forage grasses).

\section{Plant material and measurement}

The maize harvest was occurred on August $2^{\text {th }}, 2014$ and 2015 growing seasons. In order to assess the maize variables, two rows with $5 \mathrm{~m}$ of length were collected, excluding the edges to avoid data disturbed, resulting in $9 \mathrm{~m}^{2}$ of useful area in each plot. The following variables were determined at harvest: maize stand (MS), No. of maize ears (NME), stem diameter (SD), ear diameter (ED), ear length (EL), No. of rows per ear (NRE), No. of grain per row (NGR), 1000 grains weight (100GW), maize grain yield (MGY), grain weight per ear (GWE), No. of grain per ear (NGE), above-ground maize dry matter (AMDM), and harvest index (HI).

The MS and NME per hectare were determined counting the No. of plants and ear in $9 \mathrm{~m}^{2}$ in each plot and extrapolated to hectare. SD, ED and EL were determined after maize harvested manually with digital dial calipers, measuring the ear and stem diameter of central part. Ear length was measured by assistance of gradual rule in millimeters from base to top of ear, which was determined in 10 ears in each plot. NRE and NGR were determined after maize harvesting in 10 ears per plot. The $1000 \mathrm{GW}$ were determined according to seed analysis rules (Brazil, 2009).

The maize grain yield (MGY) was evaluated after harvesting and the moisture was corrected to $13 \%$. To correct the grain moisture (GM) the following equation was applied: $G M=[(I M-$ $\mathrm{CM})$ / (100 - CM)].100, where IM=initial moisture and $\mathrm{CM}=$ commercial moisture (13\%). AMDM was determined by cutting the whole plant from soil surface and drying at $65^{\circ} \mathrm{C}$ with forced until constant weight, and the $\mathrm{HI}$ was determined as Gruzska (2012).

All the measurements for forage grasses were accomplished in $9 \mathrm{~m}^{2}$ as reported by maize measurement, which compiles the useful area of evaluation in each plot. In order to determine forage grasses stand, two randomized samples were used with the assistance of iron square with dimension of $1 \times 1 \mathrm{~m}$ at 25 days after emergency. The above-ground forages dry matter (AFDM) was determined with the assistance of iron square of $1 \times 1 \mathrm{~m}$ at 50,90, 135 and 180 days after emergence in both growing season. AFDM was determined by cutting the whole plant from soil surface and dried at $65^{\circ} \mathrm{C}$ with forced until constant weight, resulting in dry matter defined in $\mathrm{kg} \mathrm{ha}^{-1}$.

\section{Statistical analysis}

The variables evaluated in the experiment were submitted to the analysis of variance (ANOVA) by the $F$-test $(P \leq 0.01)$ using the SISVAR statistical analyses software and the averages of qualitative variables were compared with Tukey $(P \leq 0.05)$. In the case of significant $(P \leq 0.01)$ difference in forage grass cutting ages, they were analysed ny polynomial equation. The correlation matrix of Person for dependable variables were defined according to relation degrees between variables and the correlation strength was defined as Hinkle et al. (2003).

\section{Conclusion}

The intercropping of maize off-season with forage grasses species with and without nicosulfuron herbicide management decreased maize grain yield. B. brizantha cv. Piatã was the forage grass that less affected maize grain yield under intercropping, even with absence of nicosulfuron herbicide suppression. The suppression with nicosulfuron herbicide decreased the dry matter production of forage grasses species. Intercropping of $P$. maximum cv. Mombaça with maize off-season showed the highest decrease in maize grain yield along with increased forage dry matter 
production for livestock. Maize intercropping with forage grasses is a viable alternative to increase maize grain yield, forage grasses dry matter and remaining the soil covered with straws with possibility of no-till seeding for next cultivation, resulting in higher sustainability of agricultural systems.

\section{Acknowledgement}

We would like to acknowledge Brazilian Agricultural Research Corporation (EMBRAPA) for financial support and Universidade Federal da Grande Dourados (UFGD) for structure offered to implement this research.

\section{References}

Asai M, Moraine M, Ryschawy J, Wit J, Hoshide AK, Martin G (2018) Critical factors for crop-livestock integration beyond the farm level: A cross analysis of worldwide case studies. Land Use Policy. 73: 184-194.

Borghi E, Crusciol CAC (2007) Produtividade de milho, espaçamento e modalidade de consorciação com Brachiaria brizantha no Sistema Plantio Direto. Pesqui Agropecu Bras. 42: 163-171.

Borghi A, Crusciol ACA, Nascente AS, Mateus GP, Martins PO, Costa C (2013a) Effects of row spacing and intercrop on maize grain yield and forage production of palisade grass. Crop Pasture Sci. 63: 1106-1113

Borghi E, Crusciol CAC, Mateus GP, Nascente AS, Martins PO (2013b) Intercropping time of maize and palisadegrass or guineagrass affecting grain yield and forage production. Crop Sci. 53: 629-636.

Brasil, Ministério da Agricultura e Reforma Agrária (2009). Regras para análise de sementes. Brasília: SNDA/DNDV CLAV. 395p.

Calonego JC, Poleto LC, Domingues FN, Tiritan CS (2011) Yield and growth of maize in different plant arrangements. Rev Agrarian. 4: 84-90.

Ceccon G, Palombo L, Matoso AO, Neto AL (2010) Uso de herbicidas no consórcio de milho safrinha com Brachiaria ruziziensis. Planta Daninha. 28: 359-364.

Claessen MEC (Org.) (1997). Manual de métodos de análise de solo. 2.ed. revisão atualizada. Rio de Janeiro: EmbrapaCNPS. p.212.

Crusciol CAC, Soratto RP, Borghi E, Matheus GP (2010) Benefits of integrating crops and tropical pastures as systems of production. Better Crops. 94: 14-16.

Crusciol CAC, Nascente AS, Mateus GP, Pariz CM, Martins PO, Borghi E (2014) Intercropping soybean and palisade grass for enhanced land use efficiency and revenue in a no till system. Eur J Agron 58: 53-62.

Derpsch R, Friedrich T, Kassam A, Hongwen L (2010) Current status of adoption of no-till farming in the world and some of its main benefits. Int J Agric Biol Eng. 3: 1-26.
Didonet AD, Rodrigues O, Mario JL, Ide F (2002) Efeito da radiação solar e temperatura na definição do número de grãos em milho. Pesqui Agropecu Bras. 37: 933-938.

Freitas MAM, Valadão DV, Souza MF, Silva AA, Saraiva DT, Freitas MM, Cecon PR, Ferreira LR (2015) Levels of nutrients and grain yield of maize intercropped with signalgrass (Brachiaria) in different arrangements of plants. Planta Daninha. 33: 49-56.

Fortes DG, Rosa Junior EJ, Rosa YBCJ, Souza FR, Gelain E (2016) Successive Cultivation of Soybean/Maize Intercropped with Urochloa brizantha topdressed with Nitrogen. Rev Bras Cienc Solo. 40: 1-9.

Hinkle DE, Wiersma W, Jurs S G (2003). Applied statistics for the behavioral sciences (5th ed.). Boston: Houghton Mifflin, 2003

Hirata Silva AC, Hirata EK, Monquero PA, Golla AR (2009) Narita $\mathrm{N}$ plantas de cobertura no controle de plantas daninhas na cultura do tomate em plantio direto. Planta Daninha. 27: 465-472.

Köppen W, Geiger R (1928). Klimate der Erde. Gotha: Verlag Justus Perthes. Wall-map.

Lourente ERP, Silva EF, Mercante FM, Serra AP, Peixoto PPP, Sereia RC, Ensinas SC, Neto ALN, Alovisi AMT, Marchetti ME, Cortez JW (2016) Agricultural management systems affect on physical, chemical and microbial soil properties. Aust J Crop Sci. 10: 683-692.

Pariz CM, Andreotti M, Buzetti S, Bergamaschine FA, Ulian NA, Furlan LC, Meirelles PRL, Cavasano FA (2011) Straw decomposition of nitrogen-fertilized grasses intercropped with irrigated maize in an integrated crop livestock system. Rev Bras Cienc Solo. 35: 2029-2037.

Pariz CM, Andreotti M, Buzetti S, Bergamaschine FA, Ulian NA, Furlan LC, Meirelles PRL, Cavasano FA (2011) Straw decomposition of nitrogen-fertilized grasses intercropped with irrigated maize in an integrated crop livestock system. Rev Bras Cienc Solo. 35: 2029-2037.

Santos HG, Jacomine PKT, Anjos LHC, Oliveira VA, Lubreras JF, Coelho MR, Almeida JA, Cunha TJF, Oliveira JB. (ed.) 2013. Sistema Brasileiro de Classificação de Solos. 3. edição revisada e ampliada. Brasília: Embrapa, 353 p.

Tsumanuma GM, Detomini ER, Hall T, Fancelli AL (2012) Establishment of Brachiarias Intercropped with Maize. Uniciências. 16: 45-50.

Viaud V, Santillàn-Carvantes P, Akkal-Corfini N, Guillou CL, Prévost-Bouré NC, Ranjard L, Menasseri-Aubry L (2018) Landscape-scale analysis of cropping system effects on soil quality in a context of crop-livestock farming. Agric Ecosyst Environ. 265: 166-177.

Vidal RA (2010). Interação negativa entre plantas: inicialismo, alelopatia e competição. Porto Alegre-RS: UFRGS. 132p. 